\title{
The Global Warming and the Possible Solution
}

\author{
José F. Ábrego \\ Departamento de Estudios del Ambiente Carr. México-Toluca S/N, La Marquesa, Ocoyoacac, México \\ Email: jose.abrego@inin.gob.mx, josefroylan.abrego@hotmail.com
}

How to cite this paper: Ábrego, J.F. (2018) The Global Warming and the Possible Solution. Journal of Geoscience and Environment Protection, 6, 118-120. https://doi.org/10.4236/gep.2018.65010

Received: February 5, 2018

Accepted: May 20, 2018

Published: May 23, 2018

Copyright $\odot 2018$ by author and Scientific Research Publishing Inc. This work is licensed under the Creative Commons Attribution International License (CC BY 4.0).

http://creativecommons.org/licenses/by/4.0/

\begin{abstract}
On this research, I proposed some solutions to diminish the global warming because we are going to precipice and it is necessary to learn some catastrophic experiences on the world. I have proposed: Recycling the exhaust gases of the cars to the machine in order to produce clean gases, in the industrial factories, to capture the $\mathrm{CO}_{2}$ gas to produce carbon and oxygen, using electromagnetic irradiation from Ultrasonic excitation. It is an economical process because we have a consume of $0.0113 \mathrm{~kJ}$ for $500 \mathrm{ml}$ of $\mathrm{CO}_{2}$ gas, and to dissociate the methane gas using a crossed electron molecular beam; and to generate electric energy research more on nuclear fusion using water as fuel and in the depletion of ozone layer, it is necessary to research more for renovating the damages on it.
\end{abstract}

\section{Keywords}

Depletion of Ozone Layer, Recycling of Exhaust Gases of Cars, Greenhouse Gases and Ultrasonic Excitation

\section{Introduction}

The global warming is a multidisciplinary problem, because it involves human activity, industrial factories, orbit changes, and methane carbon dioxide.

The effect on population, animals, forest and seawater are serious.

The principal human activity is using cars, which are emitting smog with high pollution, emitting carbon dioxide, and methane which are greenhouse gases because, they are incomplete combustions [1].

The industrial factories principally are using carbon to generate electricity and produce $\mathrm{CO}_{2}$.

With the orbit changes, we have several instabilities.

Carbon dioxide and methane are the principal powerful greenhouse gases.

Some solutions detected on my research are: the automobile industry must do 
research more on this theme in order to recycle the gases of the cars and send to the machine to produce clean gases.

The industrial factories can capture the $\mathrm{CO}_{2}$ gases and dissociate into carbon and oxygen using electromagnetic waves from an ultrasonic excitation and flotation cell [2], it is an economical process of $0.0113 \mathrm{~kJ}$ for $500 \mathrm{ml}$ of $\mathrm{CO}_{2}$ gas [3]: the ultrasonic equipment can be scaled to an industrial one. To generate electric energy it is necessarily to research more in nuclear fusion using water as fuel [4].

Also it is possible to dissociate the methane using a crossed electron molecular beam [5].

In the depletion of ozone layer, it is necessary to research more to renovate the damages on it, because it was our umbrella.

\section{Materials}

- Exhaust gases from a Nissan car Type TIIDA Model 2007 with a catalytic converter.

- Sonic cleaner ULTRAMET II, 117 Volts, 50 Hz, 125 Watts, 55 Khz.

- Flotation Cell, DENVER SIZE D-1.

- Gaseous $\mathrm{CO}_{2}$ in an industrial vessel.

- Quartz Digi-thermo (Colle Parmer).

\section{Method}

In all the problems, it was necessarily to exciting the gases in order to observe the results after analysis.

\section{Discussion}

According with one research, on around the world, we had an ozone layer which was our umbrella. When the sun irradiation was coming to the earth, from one hundred percent, fifty percent arrives the earth and another 50 percent was rejected.

The chemical industry has sent to the atmosphere chloro-fluor carbons and this chemical reactive, they had perforated some parts of the ozone layer and for these holes, the one hundred percent of the sun irradiation pass and we have big storm on the sea and sometimes the storms go to the continent and we have big rains.

When a hole of the ozone layer is in front of the forest, we have big fires.

When we have a lot of $\mathrm{CO}_{2}$ gas upper on sea. Because the sea is a regulator system of atmosphere and for this, the sea absorb $\mathrm{CO}_{2}$ gas, and the problem is that the water of the sea every time is becoming acid water and it is dangerous for some mollusk and reefs.

\section{Conclusions}

The global warming every time is more dangerous, because the population grows faster than before, and some people has to live far from the town center 
and the population needs more polluting cars to go to the work. Also the population needs more energy, and the industry has to produce articles for the population and send more chloro-fluor carbons to the atmosphere.

It is necessary that our government thinks about how to pressure the industry of cars because we are going to have very hard problems. Also it is necessary to research more to renovation of ozone layer.

\section{Acknowledgements}

I thank to my Instituto Nacional de Investigaciones Nucleares, MEXICO for the facility of my research.

\section{References}

[1] Ábrego, J.F. (2012) High Energy Detected on Exhaust Gases from Automobile Machine Using Ultrasound and Flotation Cell. Vol. 01, No. 02. www.insikapub.com

[2] Ábrego, J.F. (2010) Carbon Dioxide Dissociation and Capture by Means of Ultrasound and Flotation Cell. Journal on Applied Sciences Research, 6, 469-472,

[3] Ábrego, J.F. (2012) Energetic Determination on Carbon Dioxide (Gas) Dissociation by Means of Ultrasound and Flotation Cell. Journal of Basic and Applied Scientific Research, 2, 1193-1196.

[4] Ábrego, J.F. (2016) Development of Nuclear Fusion Using Ultrasonic Excitation on Water for to Generate Energy. Vol. 3, 34-38. https://www.ijmset.com

[5] Danko, M. (2013) Electron Impact Excitation of Methane: Determination of Appearance Energies for Dissociation Products. Journal of Physics B: Atomic, Molecular and Optical Physics, 46, Article ID: 045203.

https://doi.org/10.1088/0953-4075/46/4/045203 